WSRC-TR-99-00325

\title{
Cesium Removal and Kinetics Equilibrium: Precipitation Kinetics
}

by

M. J. Barnes

Westinghouse Savannah River Company

Savannah River Site

Aiken, South Carolina 29808

R. A. Peterson

S. R. White

\author{
RECEIVED \\ JAN 102000 \\ OSTI
}

DOE Contract No. DE-AC09-96SR18500

This paper was prepared in connection with work done under the above contract number with the U.S.

Department of Energy. By acceptance of this paper, the publisher and/or recipient acknowledges the U.S.

Government's right to retain a nonexclusive, royalty-free license in and to any copyright covering this paper, along with the right to reproduce and to authorize others to reproduce all or part of the copyrighted paper. 


\section{DISCLAIMER}

This report was prepared as an account of work sponsored by an agency of the United States Government. Neither the United States Government nor any agency thereof, nor any of their employees, makes any warranty, express or implied, or assumes any legal liability or responsibility for the accuracy, completeness, or usefulness of any information, apparatus, product or process disclosed, or represents that its use would not infringe privately owned rights. Reference herein to any specific commercial product, process or service by trade name, trademark, manufacturer, or otherwise does not necessarily constitute or imply its endorsement, recommendation, or favoring by the United States Government or any agency thereof. The views and opinions of authors expressed herein do not necessarily state or reflect those of the United States Government or any agency thereof.

This report has been reproduced directly from the best available copy.

Available for sale to the public, in paper, from: U.S. Department of Commerce, National Technical Information Service, 5285 Port Royal Road, Springfield, VA 22161, phone: (800) 553-6847

fax: (703) 605-6900

email: orders@ntis.fedworld.gov

online ordering: http://www.ntis.gov/ordering.htm

Available electronically at http://www.doe.gov/bridge

Available for a processing fee to U.S. Department of Energy and its contractors, in paper, from: U.S. Department of Energy, Office of Scientific and Technical Information, P.O. Box 62, Oak Ridge, TN 37831-0062, phone: (865) 576-8401

fax: (865) 576-5728

email: reports@adonis.osti.gov 


\section{DISCLAIMER}

Portions of this document may be illegible in electronic image products. Images are produced from the best available original document. 


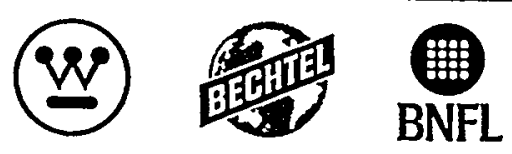

\section{DISTRIBUTION:}

W. F. Ayers, 773-41A

J. L. Barnes, 704-3N

M. J. Barnes, 773-A

S. B. Beck, 704-3N

J. T. Carter, 704-25S

G. L. Cauthen, 241-119H

W. C. Clark, 704-56H

N. R. Davis, 703-H

R. A. Dimenna, 773-42A

L. O. Dworjanyn, 735-11A

H. H. Elder, 704-S

S. D. Fink, 773-A

F. F. Fondeur, 773-A

J. R. Fowler, 704-3N

J. C. Griffin, 773-A

T. Hang, 773-42A

D. C. Hannah, 703-46A

D. T. Hobbs, 773-A

E. W. Holtzscheiter, 773-A

P. I. Hudson, 704-3N

P. R. Jackson, 703-46A

R. A. Jacobs, 704-3N

M. D. Johnson, 703-H

R. T. Jones, 704:3N

L. F. Landon, 704-T

B. L. Lewis, 703-H

T. J. Lex, 703-H

P. E. Lowe, 773-41A

D. J. McCabe, 773-42A

J. W. McCullough, 703-H

M. S. Miller, 704-56H
T. M. Monahon, 703-H

J. P. Morin, 703-H

E. T. Murphy, 704-3N

L. M. Nelson, 773-43A

L. M. Papouchado, 773-A

P. K. Paul, 773-42A

R. A. Peterson, 773-A

S. F. Piccolo, 704-3N

J. A. Pike, 704-3N

M. R. Poirier, 676-T

M. J. Polochko, 773-A

J. Reynolds, $704-19 \Subset \mathrm{N}$

K. J. Rueter, 706-S

P. L: Rutland, 704-19®

M. G. Schwenker, 703-46A

R. H. Spires, 703-H

W. E. Stevens, 773-A

P. C. Suggs, $704-196 \mathrm{~N}$

W. L. Tamosaitis, 773-A

G. A. Taylor, $704-19 \propto \mathrm{N}$

W. B. VanPelt, 773-43A

D. D. Walker, 773-A

W. R. Wilmarth, 773-42A

G. T. Wright, 773-A .

J. E. Young, 773-A

TIM, 703-43A

WPTS Files, 773-A, c/o Cathy Canada, 773-A

ITP Files c/o Cathy Smalls, 241-147H 
CESIUM REMOVAL KINETICS AND EQUILIBRIUM: PRECIPITATION KINETICS

M. J. Barnes

R. A. Peterson

S. R. White

September 8, 1999

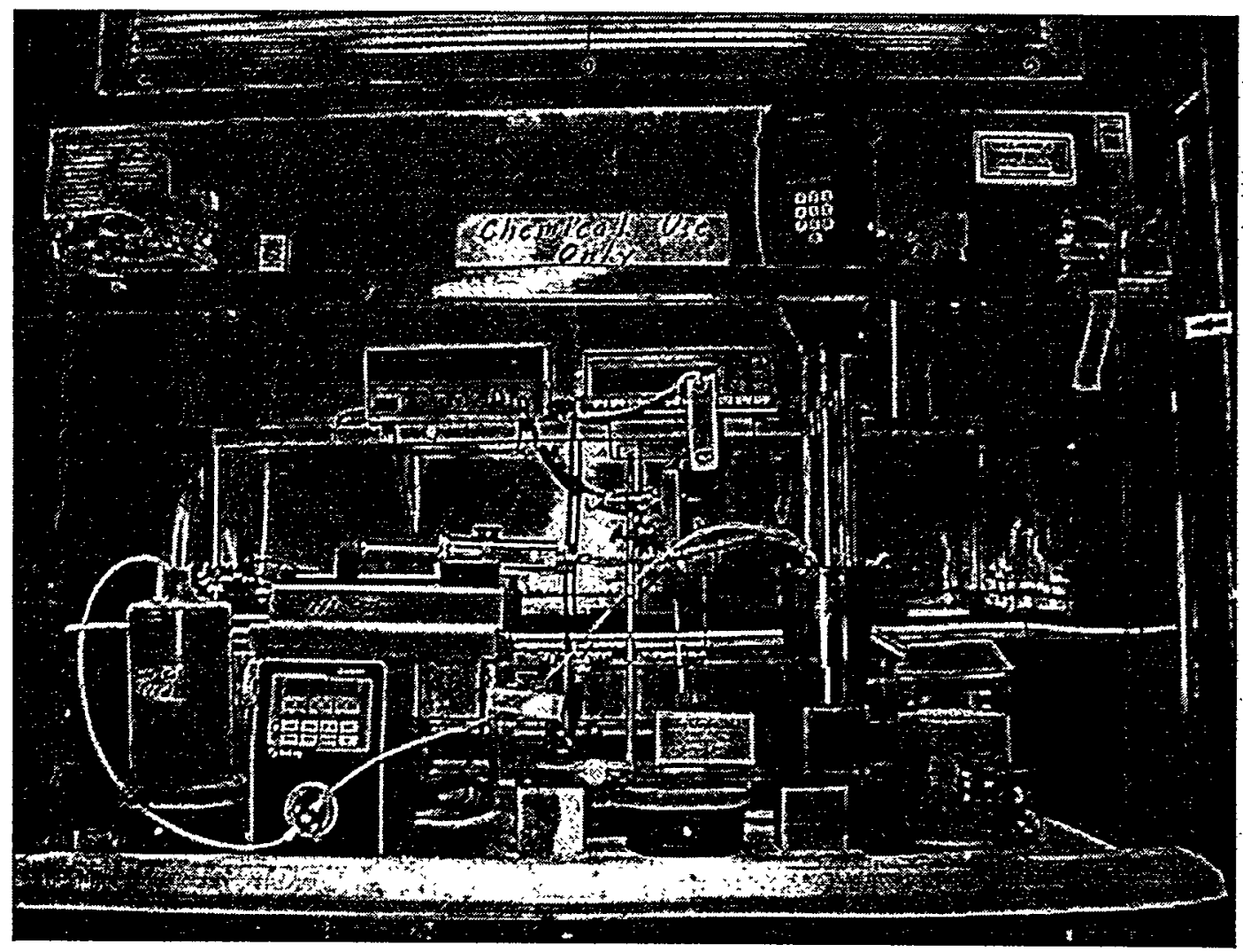

Westinghouse

Savannah River Company

Alken, SC 29808

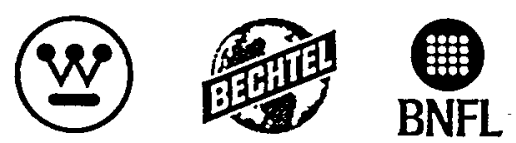


S. D. Fink

WSCR-TR-99-00325, Rev. 0

Page 2 of 18

\section{CESIUM REMOVAL KINETICS AND EQUILIBRIUM: PRECIPITATION KINETICS}

\section{AUTHORS}

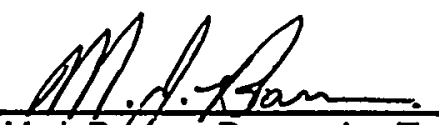

M. J. Báfhes, Processing Technology
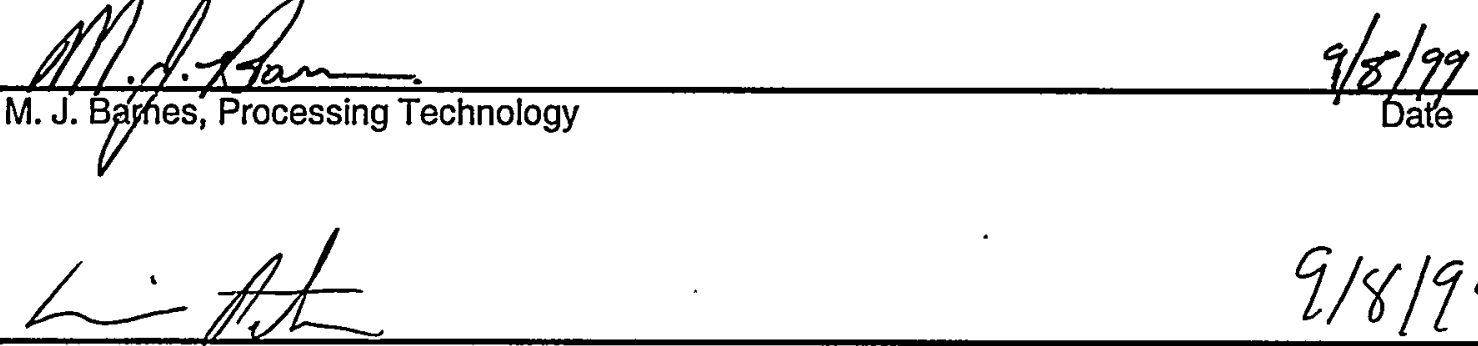

R. A. Peterson, Waste Processing Technology

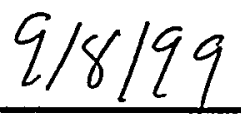

\section{DESIGN CHECK}

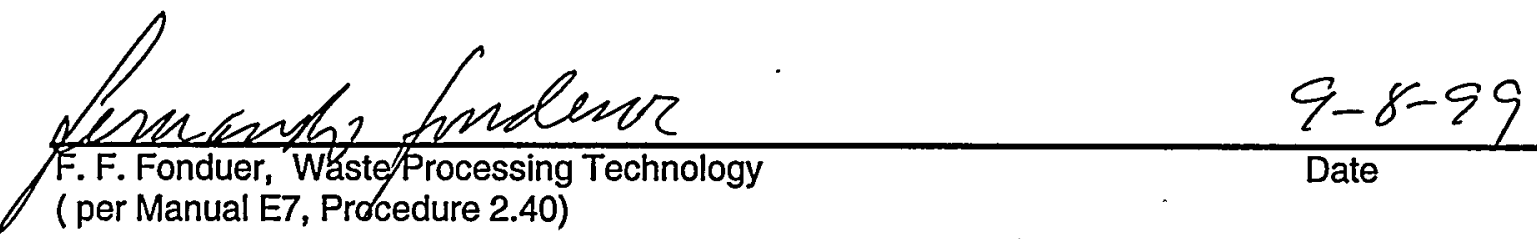

\section{APPROVALS/REVIEW}

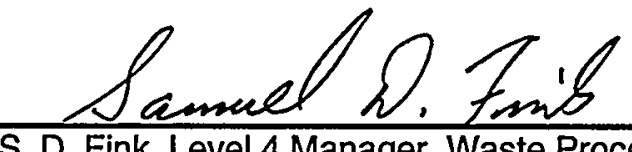

S. D. Fink, Level 4 Manager, Waste Processing Technology

$9 \cdot 8 \cdot 99$

Date 


\subsection{Summary}

This task consisted of both non-radioactive and radioactive (tracer) tests examining the influence of potentially significant variables on cesium tetraphenylborate precipitation kinetics. The work investigated the time required to reach cesium decontamination and the conditions that affect the cesium precipitation kinetics. Parameters tested include CSTR (continuous stirred tank reactor) residence time, the ionic strength of the solution (i.e., sodium concentration), the degree of agitation, and the amount of excess NaTPB present in solution. The work performed and documented herein provides CSTR decontamination factor data to define vessel size requirements, and guidance for operating parameters of the Oak Ridge National Laboratory (ORNL) 20-L integrated process demonstration. Specific conclusions and observations include the following.

- The impeller design did not significantly influence the precipitation behavior in this small-scale equipment. Additionally, poor DF performance may have masked differences due to impeller design. The occurrence of foaming in the slurries prevented additional testing to examine the influence of speed of agitation.

- Personnel addressed foaming and plugging problems through vessel reconfiguration (i.e., larger effluent port added and stilling well removed). The use of Surfynol $\$ 420$ promoted plugging of the overflow tube in this small sale equipment. Hence, we recommended not using this additive in the ORNL testing.

- Tests demonstrated that residence time is an important parameter. Increased residence times provided increased cesium and potassium decontamination.

- The amount of excess NaTPB added did not influence the precipitation reaction when added directly to the tests as a $0.55 \mathrm{M}$ solution. When partially added in a more dilute concentration, the amount of excess did influence the time to achieve decontamination.

- The ability to maintain useable (i.e., soluble) NaTPB appeared as the most significant (i.e., rate limiting) factor. Longer residence times, lower salt solution concentrations and feeding more dilute NaTPB solution each resulted in increased soluble NaTPB.

\subsection{Introduction}

The Salt Disposition Systems Engineering Team identified Small Tank Tetraphenylborate Precipitation as one of the two alternatives to replace the In-Tank Precipitation Facility at the Savannah River Site. The proposed design incorporates two continuous stirred tank reactors (CSTR). ${ }^{1}$ Prior precipitation studies used batch testing with conditions outside the proposed operating window for the CSTRs. ${ }^{2}$ The actual tank size and throughput may depend on the kinetics of the tetraphenylborate precipitation. The time required to reach cesium decontamination and the conditions that affect the cesium precipitation kinetics represent important design factors. Some of the parameters, which may affect cesium precipitation by sodium tetraphenylborate (NaTPB), include CSTR residence time, the ionic strength of the solution (i.e., sodium concentration), the degree of agitation, and the amount of excess NaTPB present in solution. High Level Waste (HLW) Process Engineering requested that the Savannah River Technology Center (SRTC) examine cesium decontamination via CSTRs. ${ }^{3}$ This report details this study.

The work performed and documented herein address the following objectives:

- Obtain CSTR decontamination factor (DF) data to confirm or redefine designed vessel size requirements.

- Provide guidance for operating parameters during the Oak Ridge National Laboratory 20-L integrated process demonstration. 


\subsection{Experimental}

This task consists of both non-radioactive and radioactive (tracer) tests examining the influence of potentially significant variables on cesium tetraphenylborate precipitation kinetics. Prior to the CSTR precipitation tests, researchers performed three non-radioactive short-duration ( $45 \mathrm{~min}$ ) tests (one with each impeller at their lowest power tested $-0.00017 \mathrm{hp}$ ) with the precipitation kinetics test equipment to examine the potential for "short-circuiting" the vessel (i.e., soluble CS-137 exiting the vessel without mixing with the NaTPB solution). Tests fed an aqueous soluble dye (dissolved in $5 \mathrm{M} \mathrm{NaCL}$ solution) into a single CSTR (residence time $=8 \mathrm{~h}$ ) initially filled with water or $\mathrm{NaCl}$ solution $(5 \mathrm{M})$ - see Photograph 1 . Personnel measured the absorbance of the dye in the overflow effluent each minute during the 45 minute tests. Using this data, we determined the concentration of the dye versus time - see Figure 1.

Comparison of the resulting curve with that expected if $1 \%$ of the dye failed to mix and routed directly through the overflow port clearly indicates that very little $(<0.25 \%)$, if any, short-circuiting occurred with any of the impellers.

Photograph 1. Equipment utilized in short-circuit testing.

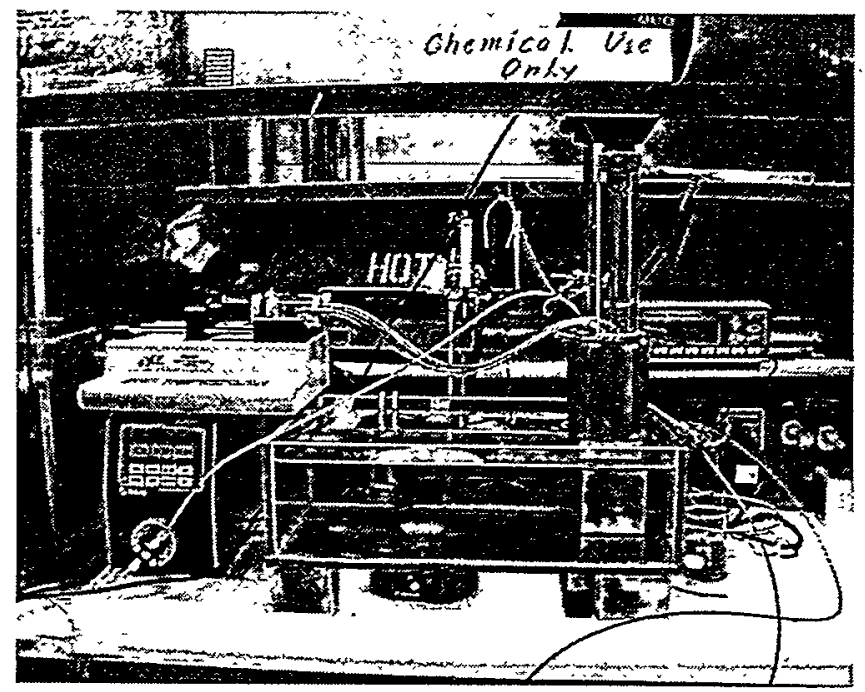

Figure 1. Short-circuit test of CSTR configuration.

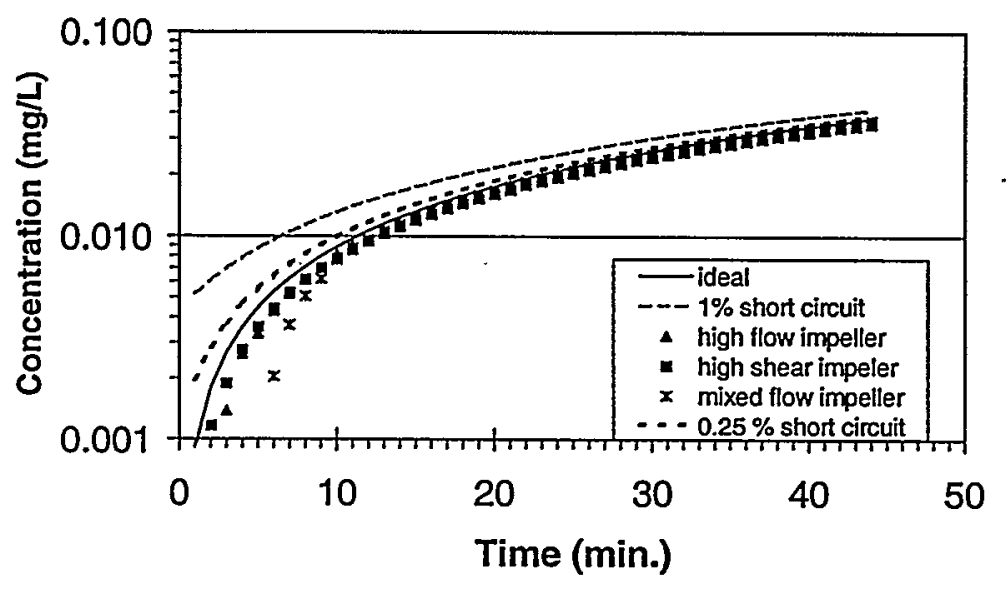


Personnel then conducted a series of single CSTR precipitation tests to examine the influence of certain parameters on the vessel's performance. Test variables studied in this task include NaTPB/KTPB molar ratio $(1.3,1.6$, and 2.0$)$, residence time $(1,4,8$, and $24 \mathrm{hr})$, and agitator type (high, mixed flow, and high shear) - see Table 1 below.

All precipitation tests used similar procedures and equipment (single 1-L CSTR fitted with baffles, overhead stirrer with 2 " impeller, 2.4 " solid wall draft tube positioned $~ 0.5^{\prime \prime}$ from CSTR bottom, and heated to $25^{\circ} \mathrm{C}$ with an external waterbath) - see Photographs $2,3,4$, and title page photograph. A piston pump delivered the salt solution waste simulant (endpoint after all additions: $4.7 \mathrm{M} \mathrm{Na}^{+}$average salt composition - see Table 2) at the desired flow rate. A syringe pump delivered the $0.55 \mathrm{M} \mathrm{NaTPB}$ solution at the desired flow rate for tests 4.1-1 through 4.4-2. Tests 9.1-9.3 involved addition of NaTPB to dilution water (added as a third stream). Varying the addition method provided information on whether introducing NaTPB in a more dilute form alters the precipitation dynamics of the continuous process. The NaTPB and salt solutions entered the vessel inside the draft tube ( $\sim .25^{\prime \prime}$ subsurface) - see Photograph 5 . An overflow tube (0.25" in Tests 4.1-1, 4.1-2, and 4.1-3 and $0.75^{\prime \prime}$ in all remaining tests) removed the resulting precipitate slurry at the desired flow rate - see Photographs 6 and 7 . Adjustments on the feed flow rates provided the desired residence time in the CSTR.

Table 1. CSTR test design parameters.

\begin{tabular}{|c|c|c|c|c|c|}
\hline Test ID & $\begin{array}{c}\text { Residence } \\
\text { Time (h) }\end{array}$ & $\begin{array}{c}\text { NaTPB/KTPB } \\
\text { Molar ratio }\end{array}$ & Radioactive & Agitator & $\begin{array}{c}\text { Agitator Power } \\
\text { (hp) }\end{array}$ \\
\hline $4.1-1$ & 8 & 1.6 & yes & mixed flow & 0.00017 \\
\hline $4.1-2$ & 8 & 1.6 & yes & high flow $^{6}$ & 0.00017 \\
\hline $4.1-3$ & 8 & 1.6 & yes & high shear $^{6}$ & 0.00017 \\
\hline $4.1-4$ & 8 & 1.6 & no & mixed flow & 0.00017 \\
\hline $4.2-1$ & 8 & 2.0 & yes & mixed flow & 0.00017 \\
\hline $4.3-1$ & 1 & 1.6 & no & mixed flow & 0.00017 \\
\hline $4.3-2$ & 1 & 1.3 & no & mixed flow & 0.00017 \\
\hline $4.4-1$ & 24 & 1.6 & no & mixed flow & 0.00017 \\
\hline $4.4-2$ & 4 & 1.6 & yes & mixed flow & 0.00017 \\
\hline 9.1 & 8 & 1.6 & yes & mixed flow & 0.00017 \\
\hline 9.2 & 8 & 1.3 & yes & mixed flow & 0.00017 \\
\hline 9.3 & 8 & 1.6 & yes & mixed flow & 0.00017 \\
\hline
\end{tabular}

Lightnin (8) A-200 classic pitched blade impeller.

Lightnin @ A-100 marine impeller.

'Lightnin® R-100 radial flow impeller.

Photograph 2. CSTR test equipment (pictured: original CSTR vessel w/ 0.25 " overflow tube, impellers, draft tubes).

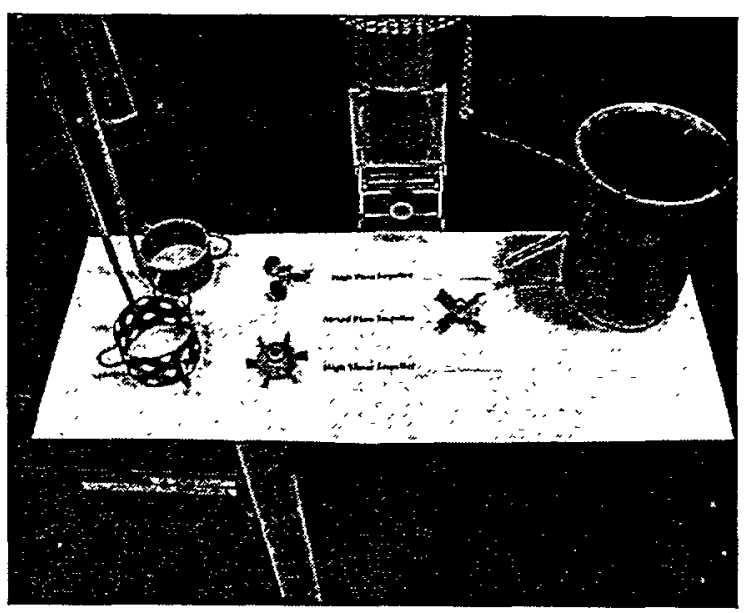


Photograph 3. Original CSTR vessel with 0.25 " overflow tube, baffles, and stilling well..

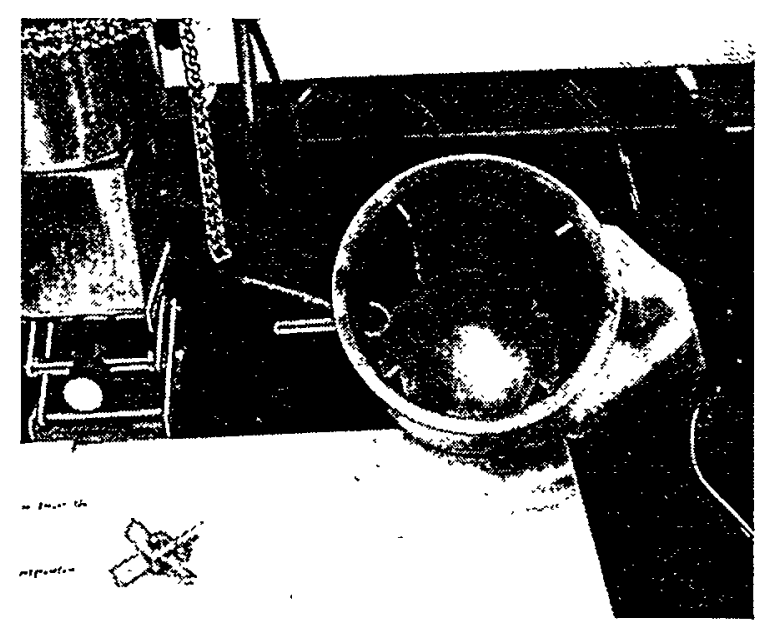

Photograph 4. The three impellers utilized in CSTR precipitation testing.

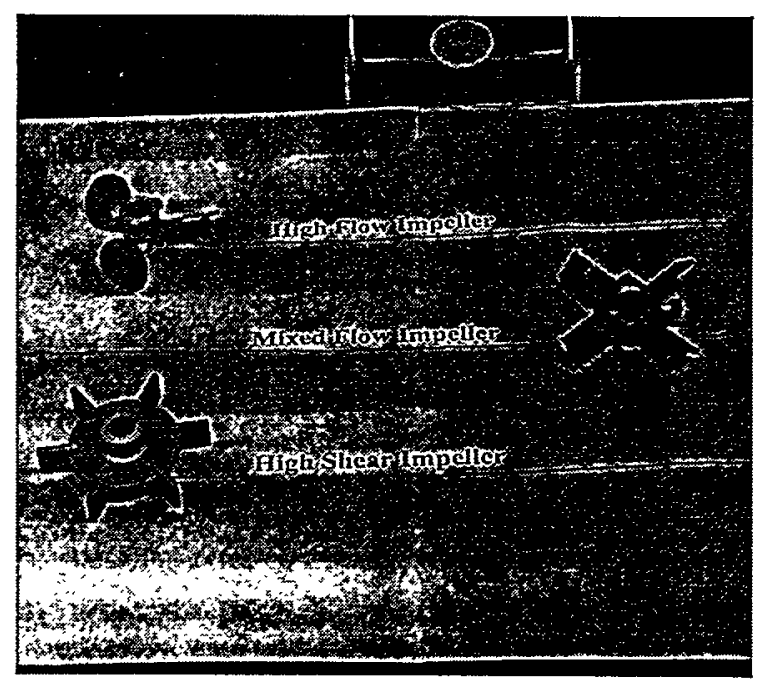

Photograph 5. Photograph of CSTR during operation showing feed downcomers and liquid surface:

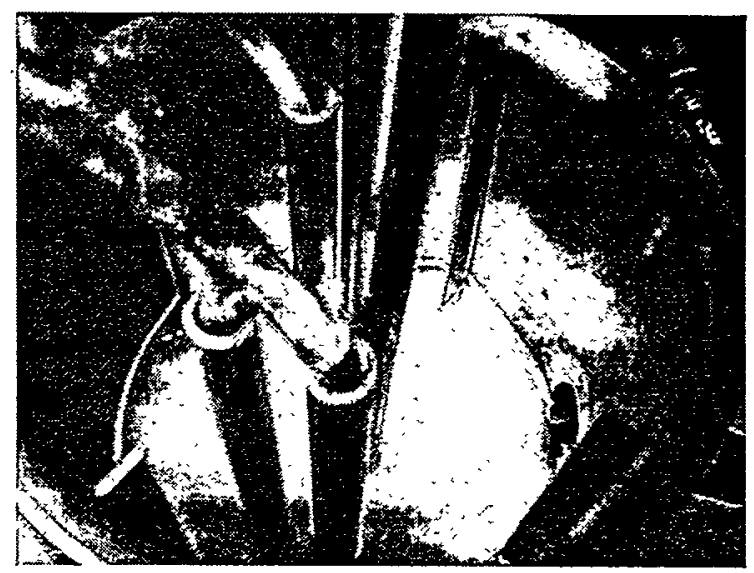


Photograph 6. Photograph of CSTR during operation showing product overflow and collection vessel.

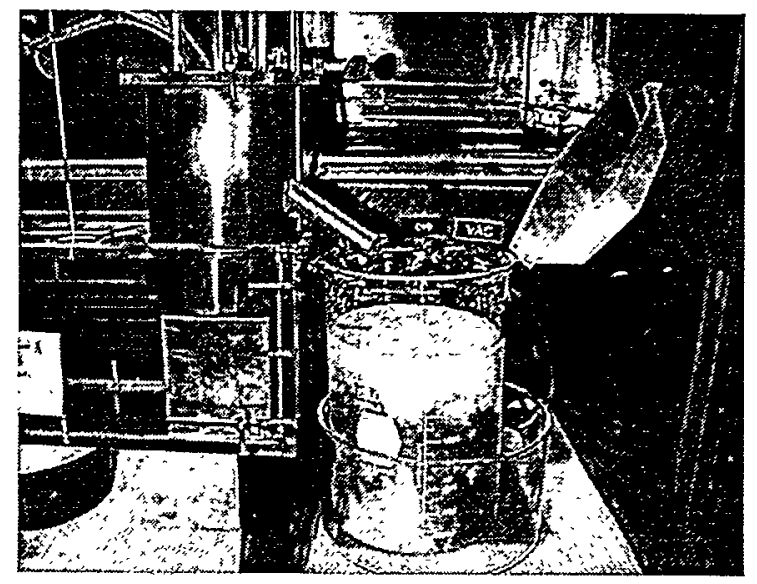

Photograph 7. Close-up photograph of precipitate product collected during CSTR operation.

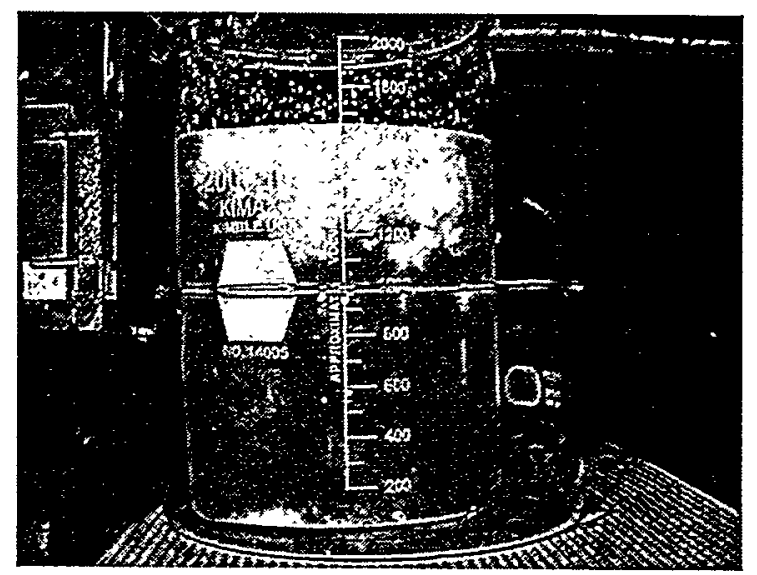

In tests 4.1-1, 4.1.-2, and 4.1-3, personnel placed $480 \mathrm{~mL}$ of previously precipitated NaTPB/KTPB/CsTPB slurry (prepared with the specified amount of excess NaTPB) in the 1-L CSTR at the start of testing. In all other tests, personnel added $550 \mathrm{~mL}$ of undiluted, unprecipitated salt solution waste simulant to the $1-L$ CSTR vessels prior to testing. This change in the start-up procedure addresses recommendations by external consultants as a means of better evaluating the performance of each test. ${ }^{5}$ An overhead variable speed paddle stirrer fitted with one of three types of impellers (high flow, mixed flow, and high shear - see Photograph 4)'agitated the solution at the desired speed throughout the entire precipitation reaction. The length of reaction time varied depending upon residence time of the test. Periodically, personnel collected $\sim 10 \mathrm{~mL}$ samples from the effluent overflow stream, immediately filtered using a 0.45 micron disposable filter, and submitted them for analysis. In non-radioactive tests, personnel measured soluble potassium and cesium by atomic absorption and inductively coupled plasma-mass spectroscopy, respectively. In the non-radioactive tests, analytical detection limits only allowed determining decontamination factors (DFs) of 1000 (based on potassium). In radioactive tracer tests, personnel monitored cesium-137 (gamma counting). In those tests, the level of Cs-137 added to the salt solution waste simulant allowed the researchers to detect cesium DFs as large as 40,000 . All tests used reagent grade chemicals weighed on calibrated balances.

Personnel added the defoaming agent Surfynol ${ }^{\otimes} 420(500 \mathrm{mg} / \mathrm{L})$ to tests $4.1-1,4.1-2$, and $4.1-3$ via the salt solution waste simulant feed stream. Foaming problems and plugging of the $0.25^{n}$ overflow tube occurred in tests 4.1-2 and 4.1-3. Clumps of Surfynol ${ }^{\circledR} 420$ formed in the tests. To mitigate these problems, personnel conducted all other tests in $1-L$ CSTRs with $0.75^{\prime \prime}$ overflow tubes with the stilling wells removed. Furthermore, the remaining tests omitted the Surfynol ${ }^{\circledast} 420$. 
Table 2. Target endpoint (after NaTPB addition) salt solution waste simulant concentration for cesium precipitation kinetics testing.

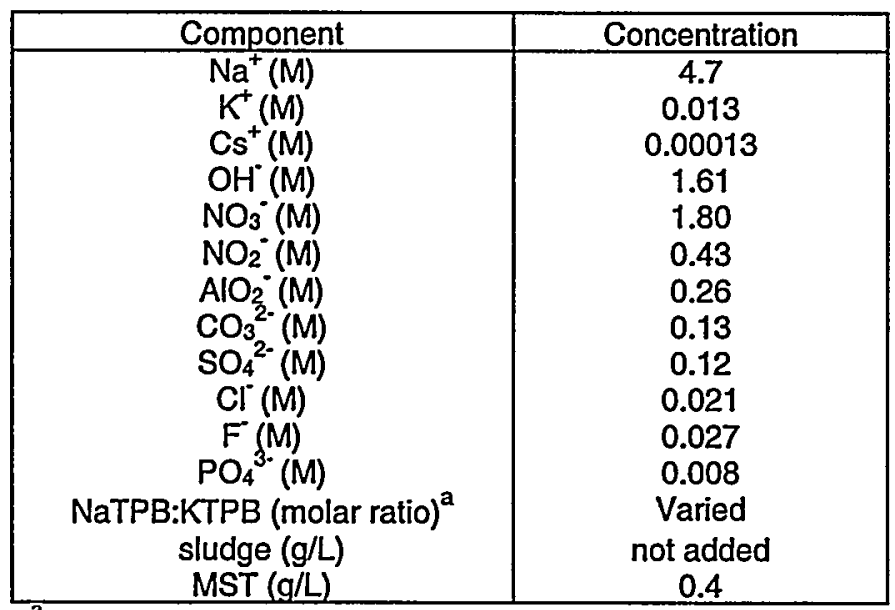

${ }^{a}$ Personnel fixed the amount of NaTPB in proportion to the molar amount of $\mathrm{K}^{+}$present in the tests.

\subsection{Results and Discussion}

\subsection{Tests $4.1-1,4.1-2$, and $4.1-3$}

Tests 4.1-1, 4.1-2, and 4.1-3 examined the influence of impeller type. Each test utilized the same level of excess NaTPB (1.6 molar ratio), residence time $(8 \mathrm{~h}$ ), and salt solution. Test $4.1-1$ used a mixed flow impeller (classic pitched blade, Power Number 1.27). Test 4.1-2 used a high flow impeller (marine, Power Number 0.77). Test 4.1-3 used a high shear impeller (radial flow - Power Number 5.75) - see Photograph 4. In each of the three tests, personnel controlled agitation at different speeds $(414,489$, and $250 \mathrm{rpm}$ for Tests 4.1-1, 4.1-2, and 4.1-3, respectively) to ensure the same power (0.00017 hp). All three settings fall within the turbulent flow regime. As noted in the previous section, all three radiotracer tests started with the CSTR filled with precipitated slurry and all three tests contained Surfynol ${ }^{\otimes} 420$. Section 8 contains the data from the three tests while Figures 2, 3, and 4 respectively, show the temporal cesium concentration profiles.

Test 4.1-1 (Figure 2) started with a precipitate heel from an earlier (failed due to plugging) test. In this case, the solution contained elevated concentrations of cesium and potassium from the outset of experiment. Slug flow (i.e., erratic surges from the overflow line) prevailed during the first half of the test. The later half of the experiment exhibited a more continuous flow. An average cesium DF of 13 occurred over the first $27 \mathrm{~h}$ of testing. A substantially higher DF (770) resulted in the final sample. The cause of this discrepancy remains unknown but may result in part from either flow control, sampling, crosscontamination'or handling problems. Potassium data show similar trends as the cesium data but with a significantly lower DF (2.8 avg. for first $27 \mathrm{~h}$ ). Additionally, the ratio of cesium to potassium changed throughout the test.

Test 4.1-2 (Figure 3) started with a batch-precipitated heel (prepared solely for startup of the test). The data indicate that the test initially started with a decontaminated solution but lost decontamination within $30 \mathrm{~h}$. Again, flow control proved difficult. In this experiment, flow remained more continuous during the first half of the test and started slugging over the last half of the test. As a result of the slug flow, personnel collected the last two samples directly from the vessel and not from the overflow tube. The fluctuations in the data again may be due to the flow control problems as well as the change in sample method or handling. The later portion of the test yielded an average cesium DF of 21. During the same time period, the average potassium DF measured 2.8. The lower potassium DF relative to Cs DF is expected due to increased solubility of KTPB (relative to CsTPB). 
Test 4.1-3 (Figure 4) provided the most consistent flow throughout the test duration. This test also started with a batch precipitated heel (again, prepared solely for startup of the test). The data indicate that the test initially started with a decontaminated solution but lost decontamination within $20 \mathrm{~h}$. The average cesium and potassium DFs from the later portion of the testing measured 27 and 3.5 , respectively.

Based upon the composite data from these three experiments, the type of impeller used did not significantly influence performance. Given the foaming behavior of the slurries, we judged additional testing to examine the influence of speed of agitation in this equipment as unproductive. As a result, all

Figure 2. Cesium-137 and potassium concentration observed in Test 4.1-1.

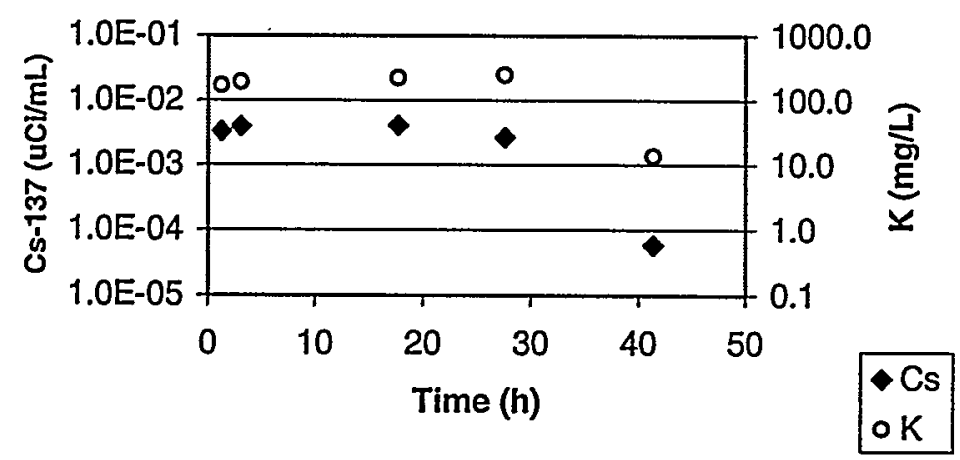

Figure 3. Cesium-137 and potassium concentration observed in Test 4.1-2.

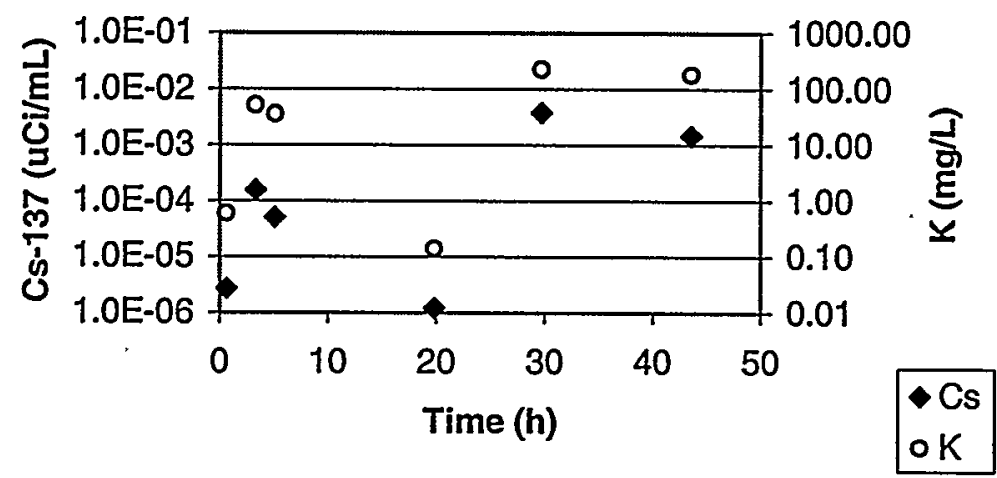

Figure 4. Cesium-137 and potassium concentration observed in Test 4.1-3.

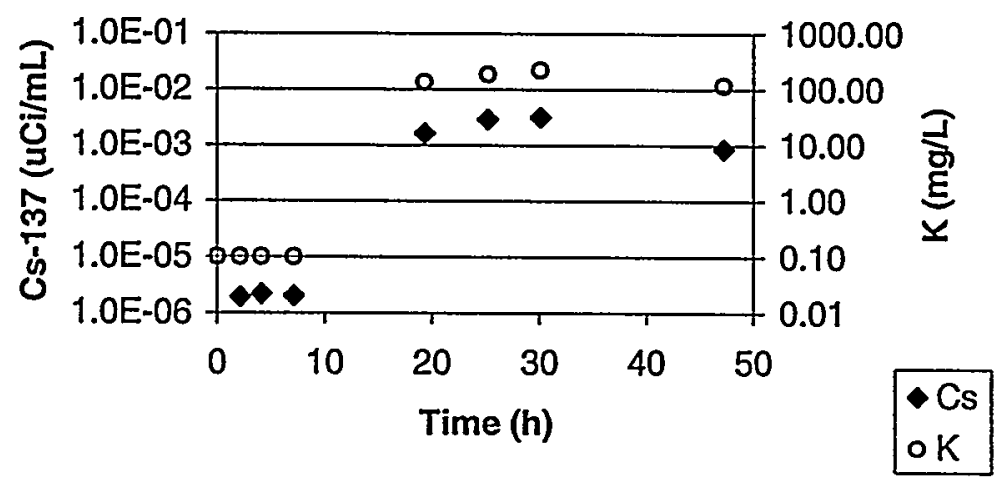


future CSTR testing used the classic pitch blade impeller at $414 \mathrm{rpm}(0.00017 \mathrm{hp})$. In addition, we altered the configuration of the CSTR vessel. All future tests used 1-L CSTRs with $0.75^{\prime \prime}$ (rather than $0.25^{\prime \prime}$ ) overflow tubes with the stilling wells removed. Additionally, the remaining tests omitted Surfynol ${ }^{\circledR} 420$. The low cesium DFs obtained also suggested that the remaining tests could use non-radioactive solutions until such time that substantially improved performance resulted.

\subsection{Test $4.1-4$}

Test 4.1-4 represented a non-radioactive repeat of Test 4.1-1. The test used a classic pitch blade impeller (414 rpm), a residence time of $8 \mathrm{~h}$, a NaTPB molar ratio of 1.6, and the same salt solution. However, the test omitted Surfynol ${ }^{\circledR} 420$ and used the newly designed CSTR vessel (i.e., larger overflow tube and no stilling well). In addition, the test started with the CSTR vessel filled with unprecipitated salt solution waste simulant. Continuous flow resulted throughout the duration of the test. The test exhibited no foam or plugging problems. Section 8 and Figure 5 provide the test data. The final $20 \mathrm{~h}$ of testing yielded an average cesium DF of 8.6. The corresponding potassium DF for the same time period measured 1.9. These values agree well the same as those observed in Test 4.1-1 (13 and 2.8, respectively). The reproducibility of the data prove that the changes made to the test equipment, start-up method, and solution (i.e., non-radioactive) did not drastically alter the precipitation behavior. Hence, the agglomeration of solids, the foaming, and the inconsistency in flow patterns -while operationally inconvenient - did not appear to detract from the efficiency of the precipitation.

\subsection{Test $4.2-1$}

Test 4.2-1 determined the influence of NaTPB excess on the reaction. The test utilized a 2.0 molar ratio (equivalent to a $100 \%$ excess) of NaTPB (relative to potassium) and Cs-137 radiotracer. In all other aspects, Test 4.2-1 remained identical to Test 4.1-4. The test used the mixed flow impeller (classic pitch blade impeller at $414 \mathrm{rpm}$ ), a residence time of $8 \mathrm{~h}$, and the same salt solution. Additionally, the test omitted Surfyno ${ }^{\otimes} 420$ and used the redesigned CSTR vessel. Furthermore, the test started with the CSTR vessel filled with unprecipitated salt solution waste simulant. Continuous flow existed throughout the duration of the test. The test exhibited no foam or plugging problems. Section 8 and Figure 6 contain the data. The final $40 \mathrm{~h}$ of testing produced an average cesium DF of 9.0. The corresponding potassium DF for the same time period measured 2.0. These values nearly equal those of Test 4.1-4 (8.6 and 1.9, respectively). The lack of deviation in the data from that of Test 4.1-4 suggest that under the conditions and design tested, the percent excess NaTPB, when added at a concentration of $0.55 \mathrm{M}$, did not influence the reaction.

\subsection{Tests $4.3-1$ and $4.3-2$}

Test 4.3-1 examined the influence of residence time on the precipitation reaction. Test 4.3-1 conditions remained identical to Test 4.1-4 with one exception: a residence time of one hour. The non-radioactive test used the mixed flow classic pitch blade impeller (414 rpm), and the same salt solution. Additionally,

Figure 5. Cesium-137 and potassium concentration observed in Test 4.1-4.

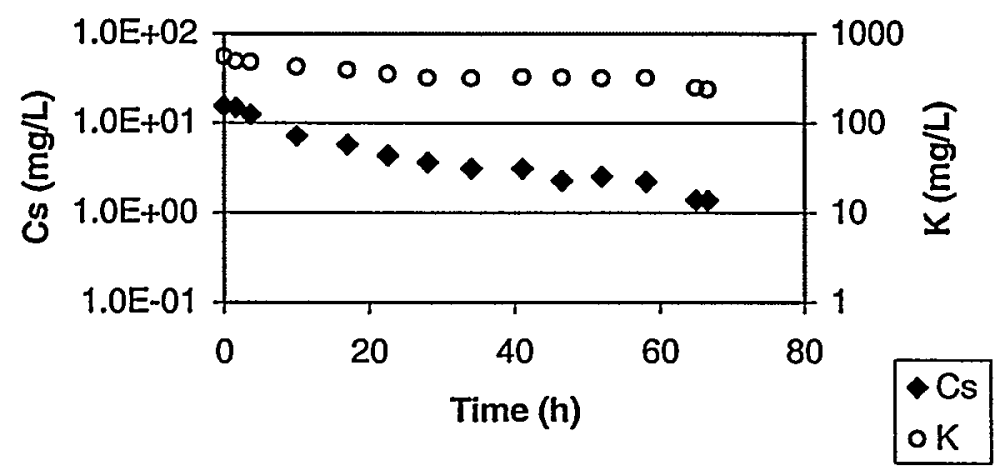


the test omitted Surfynol ${ }^{\circledast} 420$ and used the redesigned CSTR vessel. Furthermore, the test started with the CSTR vessel filled with unprecipitated salt solution waste simulant. Continuous flow occurred throughout the duration of the test. The test exhibited no foam or plugging problems. Section 8 and Figure 7 provide the data. The final 3 hours of testing yielded an average cesium DF of 5.5. The corresponding potassium DF for the same time period measured 1.4. These values appear similar to those of Test 4.1-4 (8.6 and 1.9, respectively). However, the difference, while not large, represents a measurable change (and trend) in the cesium and potassium concentrations. Recall DF is a ratio of feed concentration to effluent concentration. At low DFs (e.g., 2 or 3), a small change in DF provides a significant change in cesium concentration. At modest DFs (e.g., 10 or 15), a small change in DF does not indicate a significant change in cesium. Based upon this data, longer residence times $(\sim 24 \mathrm{~h})$ may significantly affect cesium and potassium concentrations.

Test 4.3-2, while similar to Test 4.3-1, used a NaTPB molar ratio of 1.3 (rather than 1.6 used in Test 4.31) and its salt solution waste simulant contained approximately 4.5 times as much potassium and cesium as that of Test 4.3-1. The non-radioactive test used the mixed flow classic pitch blade impeller (414 rpm). Additionally, the test omitted Surfynol ${ }^{\circledast} 420$ and used the redesigned CSTR vessel. Furthermore, the test started with the CSTR vessel filled with unprecipitated salt solution waste simulant. Continuous flow existed throughout the duration of the test. The test exhibited no foam or plugging problems. Section 8 contains the test data. Personnel collected samples every hour. However for economic reasons, personnel only analyzed the last two samples and the feed.

The final two samples provided an average cesium DF of 44 . The corresponding potassium DF for the same time period measured 5.4. These values represent a significant improvement from those of Test 4.3-1 (5.5 and 1.4, respectively). Even though Test 4.3-2 used less NaTPB molar excess (1.3 vs. 1.6),

Figure 6. Cesium-137 and potassium concentration observed in Test 4.2-1.

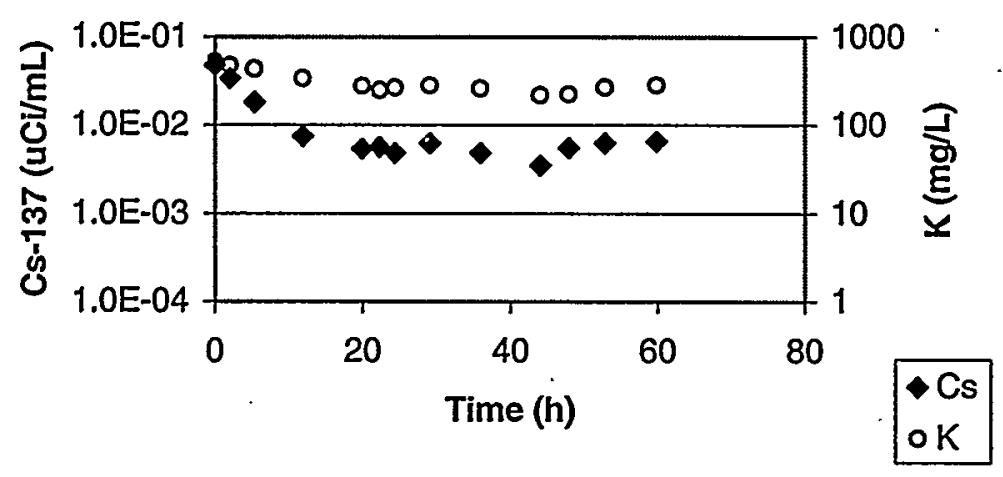

Figure 7. Cesium-137 and potassium concentration observed in Test 4.3-1.

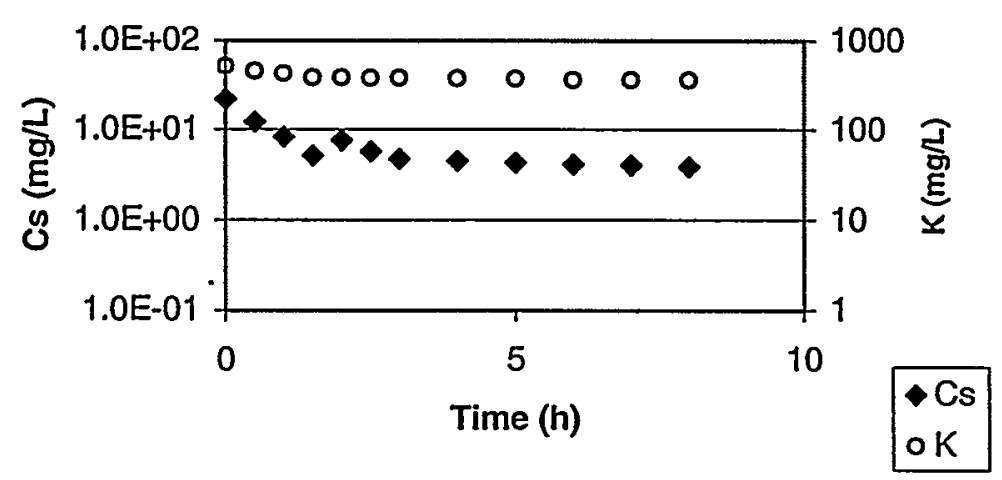


the significantly higher concentration of potassium and cesium ( $\sim 4.5$ times as much) in the feed requires a substantially increased mass of NaTPB. This increase in the mass of NaTPB provides a larger reservoir of insoluble NaTPB from which to provide soluble NaTPB.

\subsection{Tests $4.4-1$ and $4.4-2$}

Test 4.4-1 further examined the influence of residence time on the precipitation reaction. Test 4.4-1 conditions remained identical to those of Tests 4.1-4 and 4.3-1 except for the change in residence time. Test 4.4-1 utilized a residence time of $24 \mathrm{~h}$. The non-radioactive test used the mixed flow classic pitch blade impeller (414 rpm), and the same salt solution. Additionally, the test omitted Surfynol ${ }^{\otimes} 420$ and used the redesigned CSTR vessel. Furthermore, the test started with the CSTR vessel filled with unprecipitated salt solution waste simulant. Continuous flow existed throughout the duration of the test. The test exhibited no foam or plugging problems. Section 8 contains the test data. Personnel collected samples periodically over 6 days; however for economy, they only analyzed the last sample and the feed. The final sample produced a cesium DF greater than 80 (limited by detection limit). The corresponding potassium DF for the same sample exceeded 3840 (limited by detection limit).

Test 4.4-2 examined the influence of residence time and salt concentration on the precipitation kinetics. The radioactive test used a residence time of $4 \mathrm{~h}$ in conjunction with an endpoint (i.e., post NaTPB addition) sodium ion concentration of $3.5 \mathrm{M}$. The test also used the mixed flow classic pitch blade impeller (414 rpm), and the same salt solution. Additionally, the test omitted Surfynol ${ }^{\oplus} 420$ and used the redesigned CSTR vessel. Furthermore, the test started with the CSTR vessel filled with unprecipitated salt solution waste simulant. Continuous flow existed throughout the duration of the test. The test exhibited no foam or plugging problems. Section 8 contains the test data. Personnel collected samples periodically over 2 days. However, for economy, personnel only analyzed the feed, 24 and $28 \mathrm{~h}$ samples. The final sample produced a cesium DF of $>27,000$.

Data from Tests 4.4-1 and 4.4-2 demonstrate large DFs with CSTRs. The test data suggest that the effective concentration of NaTPB and the manner of addition largely govern the efficiency of performance. In Test 4.4-1, the significantly longer residence time promoted enough dissolution of insoluble NaTPB to achieve a large DF. In Test 4.4-2, the lower sodium ion concentration of the salt solution also permitted an increased rate of dissolution of insoluble NaTPB.

\subsection{Tests $9.1,9.2$, and 9.3}

Previous testing suggested the rate-limiting step in the precipitation reaction involved dissolving insoluble NaTPB. Tests 9.1,9.2, and 9.3 provided a means to determine if method of adding the NaTPB affected the precipitation kinetics by maintaining a larger quantity of soluble NaTPB. Test 9.1 conditions largely mimic those of Test 4.1-4. The exceptions include the use of a radiotracer, splitting the 1.6 relative molar excess of NaTPB. Test 9.1added the stoichiometric amount - $100 \%$ - of NaTPB as done previously via syringe pump with the remaining quantity of NaTPB - the $60 \%$ excess - added in a dilution water stream. Test 9.1 also used a more concentrated salt solution waste feed simulant, although the endpoint concentration remains the same after addition of the NaTPB bearing dilution water. The test used a classic pitch blade impeller $(414 \mathrm{rpm})$, and the same salt solution as the earlier tests. Additionally, the test omitted Surfynol@ 420 and used the redesigned CSTR vessel. Furthermore, the test started with the CSTR vessel filled with unprecipitated salt solution waste simulant. Continuous flow existed throughout the duration of the test. The test exhibited no foam or plugging problems. Section 8 and Figure 8 provide the data. The test yielded a steady state cesium DF of approximately 65 . Personnel did not analyze for potassium to minimize analytical costs. The observed Cs DF significantly improved over that of Test 4.14 (8.6). Therefore, the available quantity of soluble NaTPB appears rate limiting.

Test 9.2 further demonstrates the influence of soluble NaTPB. Test 9.2 utilized the same configuration except for use of a NaTPB relative molar excess of 1.3 instead of 1.6. This test closely approximates Test 4.3-3. Section 8 and Figure 9 contain the data. The observed Cs DF for the final sample measured 43 (as compared to 5.5 for Test 4.3-3). The reduced DF (compared with Test 9.1 ) indicates that the $30 \%$ difference in soluble NaTPB between the two tests influenced the efficiency of precipitation. 
Test 9.3 extended Test 9.2 (i.e., Test 9.2 vessel, contents, and setup remained in place with the feeds restarted at the appropriate rates). In Test 9.3, personnel changed the amount of $0.55 \mathrm{M} \mathrm{NaTPB}$ feed to the vessel to $130 \%$ of stoichiometric (with dilution water NaTPB left at $30 \%$ ). Personnel maintained all other parameters constant. In the test, the Cs-137 concentration, low at the start, increased significantly after $22 \mathrm{~h}$ of operation. The final DF of the test measured 8 . Assuming that the concentration of the added NaTPB dominates performance, one expects a poorer performance in Test 9.3 than in Test 9.1 as observed -- and nearly an equal performance as observed in Test 9.2. The result suggests that addition of NaTPB in too high a concentration even limits the efficiency of a parallel addition with a less concentrated feed. Modeling analysis of Test series 9 is provided in the Bases, Assumptions, and Results of the Flowsheet Calculations for the Decision Phase Salt Disposition Alternatives document. ${ }^{6}$

Figure 8. Cesium-137 and potassium concentration observed in Test 9.1.

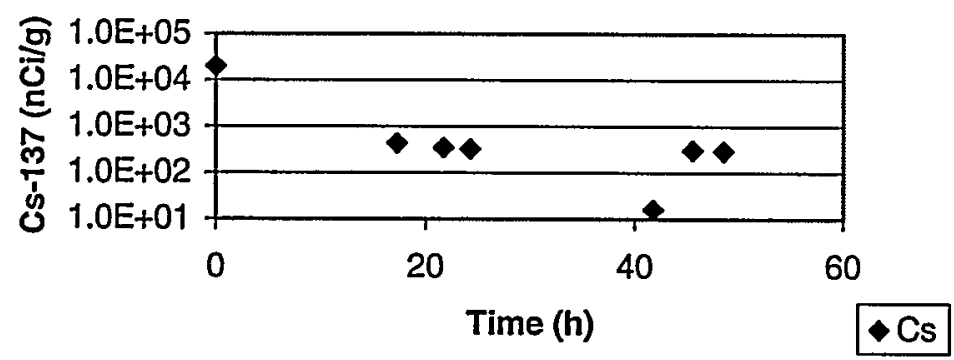

Figure 9. Cesium-137 and potassium concentration observed in Test 9.2.

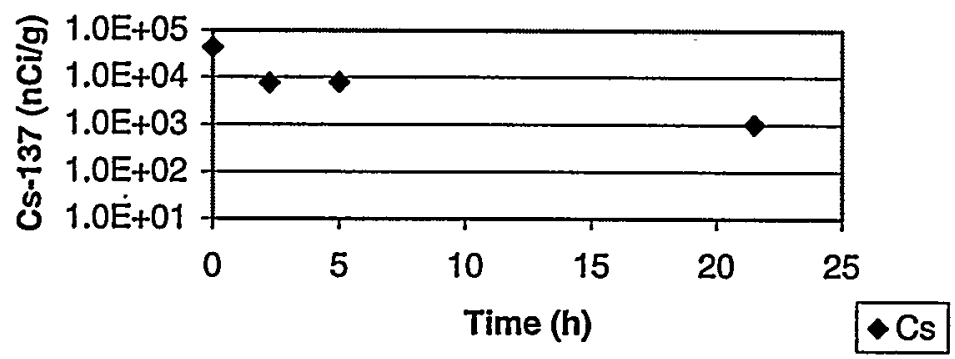

Figure 10. Cesium-137 and potassium concentration observed in Test 9.3.

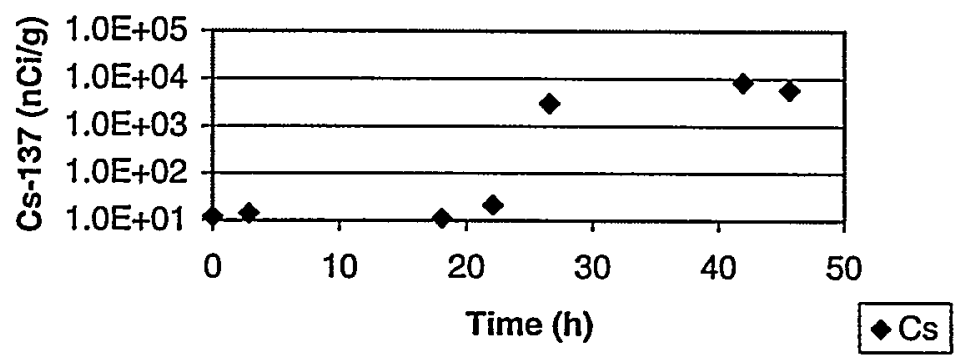




\subsection{Conclusions}

Tests examined potentially significant cesium tetraphenylborate precipitation variables. Potential influential parameters tested include CSTR residence time, the ionic strength of the solution (i.e., sodium concentration), the degree of agitation, and the amount of excess NaTPB present in solution. Specific conclusions and observations include the following.

- The impeller design did not significantly influence the precipitation behavior in this small scale equipment. Additionally, poor DF performance may have masked differences due to impeller design. The occurrence of foaming in the slurries prevented additional testing to examine the influence of speed of agitation.

- Personnel addressed foaming and plugging problems through vessel reconfiguration. The use of Surfynol@ 420 promoted plugging in this small sale equipment. Hence, we recommended not using this additive in the ORNL testing.

- Tests demonstrated that residence time is an important parameter. Increased residence times provided increased cesium and potassium decontamination.

- The amount of excess NaTPB added did not influence the reaction when added directly to the tests as a $0.55 \mathrm{M}$ solution. When partially added in a dilute concentration, the amount of excess did influence the time to achieve decontamination.

- The ability to maintain useable (i.e., soluble) NaTPB appeared as the most significant (i.e., rate limiting) factor. Longer residence times, lower salt solution concentrations and feeding more dilute NaTPB solution each resulted in increased soluble NaTPB.

\subsection{Acknowledgements}

The authors would like to thank all personnel involved in this program. Specifically, Kim Prettel, Betty Croy, Mona Blume, Nancy Gregory, Jennifer Burgess, David DiPrete, Celia Diprete, Russ Eibling, Dan Lambert, Mike Whitaker, and Sam Fink provided invaluable support. In addition, the authors would like to thank the members of the Salt Disposition Flow Sheet Team: Roy Jacobs, Hank Elder, Glenn Taylor, John Fowler, Paul Rutland, and Joe Carter for their continuous input of ideas and interpretations.

\subsection{References}

1. J.T. Carter, et al., "Bases Assumptions, and Results of the Flowsheet Calculations of the Short List Salt Disposition Alternatives", WSRC-EP-98-00168, Rev. 1, October 29, 1998

2. M. J. Barnes, "Cesium Precipitation Kinetic Studies", WSRC-TR-98-00367, Rev. 0, October 2, 1998.

3. P. L. Rutland, HLW-SDT-TTR-99-2.0, Rev. 0, January 24, 1999.

4. Cesium Removal Kinetics and Equilibrium: Precipitation and Dissolution Kinetics Task Technical and Quality Assurance Plan, WSRC-RP-99-0183, Rev. 2.

5. W. L. Tamosaitis, "Consultant Mixing and Crystallization Meeting No. 2 (U)", SRT-WPT-99-00007, June 7, 1999.

6. H. H. Elder, et. al., "Bases, Assumptions, and Results of the Flowsheet Calculations for the Decision Phase Salt Disposition Alternatives," WSRC-TR-99-0006, September 1999. 


\subsection{Appendices}

\subsection{Test 4.1-1 Data}

\begin{tabular}{|c|c|c|c|c|c|}
\hline $\begin{array}{c}\text { Time } \\
\text { (hr) }\end{array}$ & $\begin{array}{c}\text { Cs-137 } \\
(\mathrm{uCi} / \mathrm{mL})\end{array}$ & $\begin{array}{c}\mathrm{K} \\
(\mathrm{mg} / \mathrm{L})\end{array}$ & $\begin{array}{c}\text { Cs-137 } \\
\text { DF }\end{array}$ & $\begin{array}{c}\text { K } \\
\text { DF }\end{array}$ & $\begin{array}{c}\text { Cs/K DF } \\
\text { Ratio }\end{array}$ \\
\hline 0.0 & $4.50 \mathrm{E}-02$ & 550 & 1.00 & 1.00 & 1.00 \\
\hline 1.3 & $3.26 \mathrm{E}-03$ & 167 & 13.8 & 3.29 & 4.19 \\
\hline 3.1 & $3.83 \mathrm{E}-03$ & 188 & 11.8 & 2.93 & 4.01 \\
\hline 17.7 & $4.03 \mathrm{E}-03$ & 218 & 11.2 & 2.52 & 4.43 \\
\hline 27.5 & $2.64 \mathrm{E}-03$ & 243 & 17.0 & 2.26 & 7.54 \\
\hline 41.4 & $5.81 \mathrm{E}-05$ & 13.4 & 775 & 41.0 & 18.9 \\
\hline
\end{tabular}

\subsection{Test 4.1-2 Data}

\begin{tabular}{|c|c|c|c|c|c|}
\hline $\begin{array}{c}\text { Time } \\
\text { (hr) }\end{array}$ & $\begin{array}{c}\text { Cs-137 } \\
(\mathbf{u C i} / \mathrm{mL})\end{array}$ & $\begin{array}{c}\text { K } \\
(\mathrm{mg} / \mathrm{L})\end{array}$ & $\begin{array}{c}\text { Cs-137 } \\
\text { DF }\end{array}$ & $\begin{array}{c}\text { K } \\
\text { DF }\end{array}$ & $\begin{array}{c}\text { Cs/K DF } \\
\text { Ratio }\end{array}$ \\
\hline 0.0 & $4.50 \mathrm{E}-02$ & 550 & 1.00 & 1.00 & 1.00 \\
\hline 0.6 & $2.70 \mathrm{E}-06$ & 0.6 & 16700 & 917 & 18.2 \\
\hline 3.3 & $1.57 \mathrm{E}-04$ & 51.2 & 287 & 10.7 & 26.7 \\
\hline 5.1 & $5.08 \mathrm{E}-05$ & 35.4 & 886 & 15.5 & 57.0 \\
\hline 19.8 & $1.20 \mathrm{E}-06$ & 0.14 & 37500 & 3930 & 9.55 \\
\hline 29.7 & $3.82 \mathrm{E}-03$ & 223 & 11.8 & 2.47 & 4.78 \\
\hline 43.6 & $1.46 \mathrm{E}-03$ & 178.5 & 30.8 & 3.08 & 10.0 \\
\hline
\end{tabular}

\subsection{Test 4.1-3 Data}

\begin{tabular}{|c|c|c|c|c|c|}
\hline $\begin{array}{c}\text { Time } \\
(\mathrm{hr})\end{array}$ & $\begin{array}{c}\text { Cs-137 } \\
(\mathrm{uCi} / \mathrm{mL})\end{array}$ & $\begin{array}{c}\mathrm{K} \\
(\mathrm{mg} / \mathrm{L})\end{array}$ & $\begin{array}{c}\text { Cs-137 } \\
\text { DF }\end{array}$ & $\begin{array}{c}\text { K } \\
\text { DF }\end{array}$ & $\begin{array}{c}\text { Cs/K DF } \\
\text { Ratio }\end{array}$ \\
\hline 0.0 & $4.50 \mathrm{E}-02$ & 550 & 1.00 & 1.00 & 1.00 \\
\hline 2.1 & $1.90 \mathrm{E}-06$ & $<0.1$ & 23700 & $>5500$ & $<4.31$ \\
\hline 4.1 & $2.20 \mathrm{E}-06$ & $<0.1$ & 20500 & $>5500$ & $<3.72$ \\
\hline 7.1 & $2.00 \mathrm{E}-06$ & $<0.1$ & 22500 & $>5500$ & $<4.09$ \\
\hline 19.3 & $1.66 \mathrm{E}-03$ & 136 & 27.1 & 4.04 & 6.71 \\
\hline 25.1 & $2.97 \mathrm{E}-03$ & 187 & 15.2 & 2.93 & 5.16 \\
\hline 30.1 & $3.17 \mathrm{E}-03$ & 221 & 14.2 & 2.49 & 5.71 \\
\hline 47.2 & $8.59 \mathrm{E}-04$ & 118 & 52.4 & 4.65 & 11.3 \\
\hline
\end{tabular}




\subsection{Test 4.1-4 Data}

\begin{tabular}{|c|c|c|c|c|c|}
\hline $\begin{array}{c}\text { Time } \\
\text { (hr) }\end{array}$ & $\begin{array}{c}\text { Cs } \\
(\mathbf{m g} / \mathrm{L})\end{array}$ & $\begin{array}{c}\text { K } \\
(\mathbf{m g} / \mathrm{L})\end{array}$ & $\begin{array}{c}\text { Cs-137 } \\
\text { DF }\end{array}$ & $\begin{array}{c}\text { K } \\
\text { DF }\end{array}$ & $\begin{array}{c}\text { Cs/K DF } \\
\text { Ratio }\end{array}$ \\
\hline 0.0 & 15.60 & 550 & 1.00 & 1.00 & 1.00 \\
\hline 1.6 & 14.80 & 496 & 1.05 & 1.11 & 0.95 \\
\hline 3.6 & 12.40 & 480 & 1.26 & 1.15 & 1.10 \\
\hline 10.0 & 7.20 & 425 & 2.17 & 1.29 & 1.67 \\
\hline 17.0 & 5.70 & 393 & 2.74 & 1.40 & 1.96 \\
\hline 22.5 & 4.35 & 351 & 3.59 & 1.57 & 2.29 \\
\hline 28.0 & 3.60 & 321 & 4.33 & 1.71 & 2.53 \\
\hline 34.0 & 3.10 & 320 & 5.03 & 1.72 & 2.93 \\
\hline 41.0 & 3.10 & 329 & 5.03 & 1.67 & 3.01 \\
\hline 46.5 & 2.25 & 325 & 6.93 & 1.69 & 4.10 \\
\hline 52.0 & 2.54 & 317 & 6.14 & 1.74 & 3.54 \\
\hline 58.1 & 2.20 & 321 & 7.09 & 1.71 & 4.14 \\
\hline 65.0 & 1.38 & 248 & 11.3 & 2.22 & 5.10 \\
\hline 66.6 & 1.37 & 238 & 11.4 & 2.31 & 4.93 \\
\hline
\end{tabular}

\subsection{Test 4.2-1 Data}

\begin{tabular}{|c|c|c|c|c|c|}
\hline $\begin{array}{c}\text { Time } \\
\text { (hr) }\end{array}$ & $\begin{array}{c}\text { Cs-137 } \\
\text { (uCi/mL) }\end{array}$ & $\begin{array}{c}\text { K } \\
(\mathbf{m g} / \mathrm{L})\end{array}$ & $\begin{array}{c}\text { Cs-137 } \\
\text { DF }\end{array}$ & $\begin{array}{c}\text { K } \\
\text { DF }\end{array}$ & $\begin{array}{c}\text { Cs/K DF } \\
\text { Ratio }\end{array}$ \\
\hline 0.0 & 4.76 E-02 & 518 & 1.00 & 1.00 & 1.00 \\
\hline 2.0 & $3.41 \mathrm{E}-02$ & 469 & 1.40 & 1.11 & 1.26 \\
\hline 5.3 & $1.82 \mathrm{E}-02$ & 433 & 2.62 & 1.20 & 2.19 \\
\hline 11.8 & $7.44 \mathrm{E}-03$ & 339 & 6.40 & 1.53 & 4.19 \\
\hline 19.9 & $5.44 \mathrm{E}-03$ & 278 & 8.76 & 1.87 & 4.69 \\
\hline 22.3 & $5.67 \mathrm{E}-03$ & 248 & 8.40 & 2.09 & 4.02 \\
\hline 24.3 & $4.81 \mathrm{E}-03$ & 265 & 9.90 & 1.96 & 5.05 \\
\hline 29.1 & $6.20 \mathrm{E}-03$ & 280 & 7.67 & 1.85 & 4.14 \\
\hline 35.9 & $4.83 \mathrm{E}-03$ & 260 & 9.86 & 1.99 & 4.94 \\
\hline 44.0 & $3.51 \mathrm{E}-03$ & 219 & 13.6 & 2.37 & 5.73 \\
\hline 47.9 & $5.56 \mathrm{E}-03$ & 223 & 8.57 & 2.33 & 3.68 \\
\hline 52.8 & $6.32 \mathrm{E}-03$ & 269 & 7.54 & 1.93 & 3.91 \\
\hline 59.8 & $6.61 \mathrm{E}-03$ & 285 & 7.20 & 1.82 & 3.96 \\
\hline
\end{tabular}




\subsection{Test 4.3-1 Data}

\begin{tabular}{|c|c|c|c|c|c|}
\hline $\begin{array}{c}\text { Time } \\
\text { (hr) }\end{array}$ & $\begin{array}{c}\text { Cs } \\
(\mathbf{m g} / \mathrm{L})\end{array}$ & $\begin{array}{c}\mathrm{K} \\
(\mathrm{mg} / \mathrm{L})\end{array}$ & $\begin{array}{c}\text { Cs-137 } \\
\text { DF }\end{array}$ & $\begin{array}{c}\text { K } \\
\text { DF }\end{array}$ & $\begin{array}{c}\text { Cs/K DF } \\
\text { Ratio }\end{array}$ \\
\hline 0.0 & 22.10 & 517 & 1.00 & 1.00 & 1.00 \\
\hline 0.5 & 12.09 & 453 & 1.83 & 1.14 & 1.60 \\
\hline 1.0 & 8.28 & 427 & 2.67 & 1.21 & 2.21 \\
\hline 1.5 & 5.13 & 383 & 4.31 & 1.35 & 3.19 \\
\hline 2.0 & 7.62 & 381 & 2.90 & 1.36 & 2.14 \\
\hline 2.5 & 5.76 & 378 & 3.84 & 1.37 & 2.81 \\
\hline 3.0 & 4.72 & 378 & 4.68 & 1.37 & 3.43 \\
\hline 4.0 & 4.47 & 374 & 4.95 & 1.38 & 3.58 \\
\hline 5.0 & 4.27 & 370 & 5.18 & 1.40 & 3.70 \\
\hline 6.0 & 4.10 & 358 & 5.39 & 1.44 & 3.73 \\
\hline 7.0 & 4.00 & 358 & 5.53 & 1.44 & 3.83 \\
\hline 8.0 & 3.87 & 356 & 5.71 & 1.45 & 3.94 \\
\hline
\end{tabular}

\subsection{Test 4.3-2 Data}

\begin{tabular}{|c|c|c|c|c|c|}
\hline $\begin{array}{c}\text { Time } \\
\text { (hr) }\end{array}$ & $\begin{array}{c}\text { Cs } \\
(\mathbf{m g} / \mathrm{L})\end{array}$ & $\begin{array}{c}\text { K } \\
(\mathbf{m g} / \mathrm{L})\end{array}$ & $\begin{array}{c}\text { Cs-137 } \\
\text { DF }\end{array}$ & $\begin{array}{c}\text { K } \\
\text { DF }\end{array}$ & $\begin{array}{c}\text { Cs/K DF } \\
\text { Ratio }\end{array}$ \\
\hline 0.0 & 57.4 & 1700 & 1.00 & 1.00 & 1.00 \\
\hline 7.0 & 1.3 & 332 & 44.5 & 5.12 & 8.69 \\
\hline 8.0 & 1.3 & 303 & 44.5 & 5.62 & 7.92 \\
\hline
\end{tabular}

\subsection{Test 4.4-1 Data}

\begin{tabular}{|c|c|c|c|c|c|}
\hline $\begin{array}{c}\text { Time } \\
\text { (hr) }\end{array}$ & $\begin{array}{c}\text { Cs } \\
(\mathrm{mg} / \mathrm{L})\end{array}$ & $\begin{array}{c}\mathrm{K} \\
(\mathrm{mg} / \mathrm{L})\end{array}$ & $\begin{array}{c}\text { Cs-137 } \\
\text { DF }\end{array}$ & $\begin{array}{c}\mathrm{K} \\
\text { DF }\end{array}$ & $\begin{array}{c}\text { Cs/K DF } \\
\text { Ratio }\end{array}$ \\
\hline 0.0 & 30.4 & 519 & 1.00 & 1.00 & 1.00 \\
\hline 140.4 & $<0.4$ & $<0.135$ & $>80$ & $>3840$ & - \\
\hline
\end{tabular}

\subsection{Test 4.4-2 Data}

\begin{tabular}{|c|c|c|}
\hline $\begin{array}{c}\text { Time } \\
(\mathrm{hr})\end{array}$ & $\begin{array}{c}\text { Cs-137 } \\
(\mathrm{uCi} / \mathrm{mL})\end{array}$ & $\begin{array}{c}\text { Cs-137 } \\
\text { DF }\end{array}$ \\
\hline 0.0 & $4.5 \mathrm{E}-02$ & 1.0 \\
\hline 24.0 & $2.4 \mathrm{E}-05$ & 1900 \\
\hline 28.0 & $<1.7 \mathrm{E}-6$ & $>27,000$ \\
\hline
\end{tabular}


S. D. Fink

WSCR-TR-99-00325, Rev. 0

Page 18 of 18

\subsection{Test 9.1 Data}

\begin{tabular}{|c|c|c|}
\hline Time (hr) & $\begin{array}{c}\text { Cs -137 } \\
\text { (nCi/g) }\end{array}$ & DF \\
\hline 0.00 & 20052 & 1 \\
\hline 17.25 & 434 & 46 \\
\hline 21.67 & 341 & 59 \\
\hline 24.25 & 323 & 62 \\
\hline 41.75 & 160 & 125 \\
\hline 45.50 & 304 & 66 \\
\hline 48.50 & 292 & 69 \\
\hline
\end{tabular}

\subsection{Test 9.2 Data}

\begin{tabular}{|c|c|c|}
\hline Time (hr) & $\begin{array}{c}\text { Cs -137 } \\
\text { (nCi/g) }\end{array}$ & DF \\
\hline 0.00 & 43312 & 1 \\
\hline 2.25 & 7566 & 6 \\
\hline 5.00 & 7848 & 6 \\
\hline 21.50 & 1010 & 43 \\
\hline
\end{tabular}

\subsection{Test 9.3 Data}

\begin{tabular}{|c|c|c|}
\hline Time (hr) & $\begin{array}{c}\text { Cs -137 } \\
\text { (nCi/g) }\end{array}$ & DF \\
\hline 0.00 & 12 & 3609 \\
\hline 2.83 & 14 & 3094 \\
\hline 18.08 & 11 & 3937 \\
\hline 22.08 & 21 & 2062 \\
\hline 26.58 & 3019 & 14 \\
\hline 41.92 & 8211 & 5 \\
\hline 45.67 & 5721 & 8 \\
\hline
\end{tabular}

